\title{
Effect of Different Levels of Zinc and Sulphur on Yield and Yield Attributing Characters of Indian Mustard
}

\author{
Vikas Verma $^{1 *}$, C.L. Maurya ${ }^{1}$, Sourabh Tomar ${ }^{2}$ and Rishi Pal Singh ${ }^{3}$ \\ ${ }^{1}$ Department of Seed Science and Technology, ${ }^{2}$ Department of Horticulture, Chandra Shekhar \\ Azad University of Agriculture and Technology, Kanpur (U.P.) 208 002, India \\ ${ }^{3}$ Department of Entomology, Sardar Vallabhbhai Patel University of Agriculture and \\ Technology, Meerut- 250110, India \\ *Corresponding author
}

\section{A B S T R A C T}

A field experiment and laboratory experiment was conducted in Split Plot Design with three replications during 2011-12 and 2012-13 on Indian mustard variety Urvashi at New Dairy Farm, Kalyanpur, Kanpur and Seed Testing Laboratory of Department of Seed

\section{Keywords}

Mustard, Zinc, Sulphur, Effect, Yield

Article Info

Accepted:

10 June 2018

Available Online:

10 July 2018 \section{Science and Technology, respectively. Six doses of zinc and sulphur viz. 0.0, 2.5, 5.0, 7.5,} $10.0,12.5 \mathrm{Kg} \mathrm{ha}^{-1}$ and $0,10,20,30,40,50 \mathrm{Kg} \mathrm{ha}^{-1}$, respectively were applied as basal dose. Results showed that the application of zinc and sulphur affected significantly to all parameters. The dose $10 \mathrm{Kg} \mathrm{Zn} \mathrm{ha}^{-1}$ and $50 \mathrm{Kg} \mathrm{S}^{-1}$ recorded highest number of primary branches plant $^{-1}$ (6.74 and 7.99), number of secondary branches plant ${ }^{-1}$ (11.23 and 12.60), days to $50 \%$ flowering (61.10 and 61.18), number of seeds siliqua ${ }^{-1}$ (13.22 and 14.36), raw seed yield (2.42 and $2.53 \mathrm{Kg} \mathrm{plot}^{-1}$ and 2680.33 and $2816.19 \mathrm{Kg} \mathrm{ha}^{-1}$ ), graded seed yield (2.24 and $2.48 \mathrm{Kg} \mathrm{plot}^{-1}$ and 2482.54 and $2747.15 \mathrm{Kg} \mathrm{ha}^{-1}$ ), respectively. Like-wise, 12.5 $\mathrm{kg} \mathrm{Zn}$ and $50 \mathrm{Kg} \mathrm{S}^{-1}$ had registered maximum plant height $(181.34$ and $183.68 \mathrm{~cm})$, length of siliqua $(4.89$ and $5.01 \mathrm{~cm})$. The application of $10.0 \mathrm{~kg} \mathrm{Zn} \mathrm{ha}^{-1}$ and $40 \mathrm{Kg} \mathrm{S} \mathrm{ha}{ }^{-1}$ increased days to maturity (134.64 and 135.08), respectively. Maximum number of siliquae plant ${ }^{-1}$ (272.72 and 301.13) and 1000-seed weight (5.30 and $\left.5.72 \mathrm{~g}\right)$ was recorded in $7.5 \mathrm{Kg} \mathrm{Zn} \mathrm{ha}^{-1}$ and $50 \mathrm{Kg} \mathrm{S}^{-1}$, respectively.

\section{Introduction}

Mustrad (Brasica juncea, (L) Czem and cross) is important Rabi oilseed crop which belongs to family "Cruciferae". India is first position in area and second position in production after China. India is the fourth largest oilseed economy in the world. Oilseed crops hold a sizeable share of the country's gross cropped area (13\%) and contribute around $3 \%$ of gross national product and $10 \%$ of the value of all agricultural commodities (Anonymous, 2014). The area, production and productivity of rapeseed-mustard is 6.70 and 34.19 million ha, 7.96 and 63.09 million tonnes and 1188 and $1850 \mathrm{~kg} \mathrm{ha} \mathrm{ha}^{-1}$, respectively in India and world during 20132014 (Anonymous, 2014).

The average productivity of oilseeds in the country is only $1153 \mathrm{~kg} \mathrm{ha}^{-1}$. As soils of U.P. 
are deficient in zinc and sulphur, this study will facilitate in the improvement of yield and seed quality in our state. On an average oilseed crops absorb 11-12 kg sulphur to produce one tonne $(1000 \mathrm{~kg})$ of seed. Average sulphur content in seed of mustard is $1.1 \%$ as compared to $0.3 \%$ in pulses and $0.2 \%$ in cereals. Sulphur is a key nutrient for oilseed production, because in the plants, sulphur is directly involved in the formation of oil compounds. In rapeseed and mustard sulphur deficient plants have leaves which are more erect than normal and cupped inwards. Initially the underside of the leaves develops a red colour which can extend to the upper surface of leaves as well (Anonymous, 2004).

High crop yield in agriculturally progressive districts of India removed substantial amounts of micronutrients especially zinc from soil, causing yield reduction (Deb and Sakal, 2002). Sulphur increased the yield of mustard by 12 to $48 \%$ under irrigation, and by 17 $124 \%$ under rainfed conditions (Aulakh and Pasricha, 1988). In terms of agronomic efficiency, each kilogram of sulphur increases the yield of mustard by $7.7 \mathrm{~kg} \mathrm{ha}^{-1}$ (Katyal et al., 1997).

Zinc is an essential micronutrient for plant growth and is absorbed by the plant roots in the form of $\mathrm{Zn}^{2+}$. It is involved in diverse metabolic activities, influences the activities of hydrogenase and carbonic anhydrase, synthesis of cytochrome and the stabilization of ribosomal fractions and auxin metabolism (Tisdale et al., 1984).

Zinc plays vital role in carbohydrate and proteins metabolism as well as it controls the plant growth hormone IAA. It is essential component of dehydrogenase, proteinase and promotes starch formation, seed maturation and production (Marschner, 1995).

\section{Materials and Methods}

The experiment was conducted at the New Dairy Research Farm, Chandra Shekhar Azad University of Agriculture and Technology, Kalyanpur, Kanpur UP during 2011-12 and 2012-13 Indian mustard variety Urvashi under Split Plot Design with three replications having plant distance $45 \mathrm{~cm}$ and $5 \mathrm{~cm}$ respectively. Five rows were sown in each plot of $4 \times 2.25 \mathrm{~m}^{2}$.

The recommended fertilizer was applied at the rate of $120 \mathrm{Kg} \mathrm{N}, 60 \mathrm{Kg} \mathrm{P}_{2} \mathrm{O}_{5}$ and $40 \mathrm{Kg} \mathrm{K}_{2} \mathrm{O}$ $\mathrm{ha}^{-1}$ uniformly in all plots as feeder dose and plant protection measure were Spraying of Malathion50 EC @ 1 liter dissolved in 1000 liters of water ha ${ }^{-1}$ for the control of hairy caterpillar. Spraying of Imidachloroprid 17.8 EC@ $375 \mathrm{ml}$ in 1000 liters of water ha ${ }^{-1}$ was applied as per requirement for the control of aphids.

The study was consisted of two factors viz. zinc and sulphur with Six doses of zinc and sulphur viz. $0.0,2.5,5.0,7.5,10.0,12.5 \mathrm{Kg}$ $\mathrm{ha}^{-1}$ and $0,10,20,30,40,50 \mathrm{Kg} \mathrm{ha}{ }^{-1}$, respectively were applied as basal dose.

The composition of soil of the experimental plot is alluvial in nature. The soil samples were drawn and analyzed in the Soil Testing Laboratory Chandra Shekhar Azad University of Agriculture and Technology, Kanpur for different physical and chemical composition following the standard procedure. Observations were Recorded: Plant Height (cm), Number of Primary and Secondary Branches Plant ${ }^{-1}$, Days to $50 \%$ Flowering, Number of Siliquae Plant ${ }^{-1}$, Length of Siliqua (cm), Number of Seeds Siliqua ${ }^{-1}$, Days to Maturity, Raw Seed Yield (Kg plot $\left.{ }^{-1}\right)$, Raw Seed Yield $\left(\mathrm{Kg} \mathrm{ha}^{-1}\right)$, Graded Seed Yield (Kg plot $\left.^{-1}\right)$, Graded Seed Yield $\left(\mathrm{Kg} \mathrm{ha}^{-1}\right)$ and 1000 Seed Weight. 


\section{Results and Discussion}

Effect of zinc, sulphur and their interaction on yield attributing characters and yield of indian mustard

\section{Plant height}

It is evident from the data Table 1 and that the application of different doses of zinc influenced significantly on plant height of Indian mustard. The treatment of $\mathrm{Zn}_{0}, \mathrm{Zn}_{1}, \mathrm{Zn}_{2}$ and $Z n_{5}$ showed significantly effect except $Z n_{3}$ and $\mathrm{Zn}_{4}$. Application of 7.5 and $10.0 \mathrm{Kg} \mathrm{Zn}$ $\mathrm{ha}^{-1}\left(\mathrm{Zn}_{3}\right.$ and $\left.\mathrm{Zn}_{4}\right)$ did not differ significantly on plant height of mustard. Application of highest tested dose of $\mathrm{Zn}_{5}$ produced significantly tallest plant $(181.34 \mathrm{~cm})$ of Indian mustard than the rest of the doses of zinc. The shortest plant $(176.33 \mathrm{~cm})$ of Indian mustard was obtained in the control plot $\left(\mathrm{Zn}_{0}\right)$.

Every increasing dose of sulphur up to $40 \mathrm{Kg}$ $\mathrm{S} \mathrm{ha}^{-1}$ significantly increased plant height of Indian mustard (Table 1). Significantly highest plant height $(183.68 \mathrm{~cm})$ of Indian mustard was obtained with the application of $\mathrm{S}_{5}$ than the other doses of sulphur and it was nonsignificant with the application of $\mathrm{S}_{4}$. Application $\mathrm{S}_{4}$ also ranked second best treatment with significantly taller plant $(182.73 \mathrm{~cm})$ of Indian mustard than the rest of the treatments. Shortest plant $(174.67 \mathrm{~cm})$ of Indian mustard was obtained without sulphur applied plot.

\section{Number of primary branches}

Revealed significant effect on number of primary branches plant ${ }^{-1}$ with the application of various doses of zinc. It is apparent from the Table 1 that the every increasing dose of zinc significantly increased the number of primary branches plant ${ }^{1}$ during investigation. Significantly highest number of primary branches plant ${ }^{-1}$ (6.81) of Indian mustard was obtained with the application of highest tested dose $\mathrm{Zn}_{5}$ followed by $\mathrm{Zn}_{4}$ (6.74), $\mathrm{Zn} 3$ (6.32), $\mathrm{Zn}_{2}$ (6.14) and $\mathrm{Zn}_{1}$ (5.91). The treatment $\mathrm{Zn}_{2}$ and $Z_{3}$ and $Z_{4}$ and $Z n_{5}$ did not exhibit significant difference. Without zinc applied plot $\left(\mathrm{Zn}_{0}\right)$ recorded minimum number of primary branches plant $^{-1}$ (5.64) of Indian mustard.

It has been observed that every increasing dose of sulphur significantly increased number of primary branches plant ${ }^{-1}$ of Indian mustard. Significantly highest number of primary branches (7.99) plant $^{-1}$ of Indian mustard was recorded with the application of $\mathrm{S}_{5}$ as compared to rest of the doses of sulphur during experimentation. The minimum number of primary branches plant $^{-1}$ (4.46) of Indian mustard was obtained in control (Table 1).

\section{Number of secondary branches plant ${ }^{-1}$}

The data pertaining to number of secondary branches plant ${ }^{-1}$ was significantly influenced by different levels of zinc application. Every increasing doses of zinc significantly increased the number of secondary branches plant $^{-1}$ of Indian mustard during experimentation. All treatments exhibited significant difference to one other except $Z_{4}$ and $\mathrm{Zn}_{5}$. Treatment $\mathrm{Zn}_{4}$ and $\mathrm{Zn}_{5}$ did not show significant difference. Highest tested dose of $\mathrm{Zn}_{5}$ produced highest number of secondary branches plant $^{-1}$ (11.38) of Indian mustard as compared to rest of the treatments (Table 1). It was also observed that the application of $\mathrm{Zn}_{4}$ ranked second best treatment to produced more number of secondary branches plant ${ }^{-1}$ (11.23) followed by $\mathrm{Zn}_{3}$ (10.67), $\mathrm{Zn}_{2}$ (10.18) and $\mathrm{Zn}_{1}$ (9.90). The minimum number of secondary branches plant ${ }^{-1}$ (9.69) of Indian mustard was obtained without zinc applied plot.

Appendix X indicated that the application of different levels of sulphur was significantly influenced the number of secondary branches 
plant $^{-1}$ of Indian mustard. Table 1 disclose that different levels of sulphur $S_{0}, S_{1}, S_{2}, S_{3}, S_{4}$ and $\mathrm{S}_{5}$ differed statistically significant to each other with respect to number of secondary branches plant ${ }^{-1}$. It was noticed that the every increasing dose of sulphur significantly increased the number of secondary branches plant $^{-1}$ of Indian mustard. Significantly maximum number of secondary branches plant $^{-1}$ (12.60) of Indian mustard was obtained with the application $\mathrm{S}_{5}$ while minimum number of secondary branches plant ${ }^{-1}$ (8.72) was obtained in control plot.

\section{Days to $50 \%$ flowering}

Table 1 indicates that the application of various doses of zinc significantly influenced the days taken for $50 \%$ flowering of Indian mustard. Every increasing dose of zinc significantly increased the days taken for $50 \%$ flowering. The treatment $\mathrm{Zn}_{0}, \mathrm{Zn}_{1}, \mathrm{Zn}_{2}$ and $\mathrm{Zn}_{3}$ showed significant effect to each other except $Z_{4}$ and $Z_{5}$. The treatment $Z_{4}$ showed at par than $\mathrm{Zn}_{5}$ on days to $50 \%$ flowering. The maximum number of days taken for $50 \%$ flowering (60.24) was recorded under regime of dose $\mathrm{Zn}_{5}$ as compared to other doses of zinc. It can also be observed in Table 1 that more number of days taken to $50 \%$ flowering (60.04) of Indian mustard was obtained with the application of $\mathrm{Zn}_{4}$ followed by $\mathrm{Zn}_{3}$ (59.48), $\mathrm{Zn}_{2}$ (58.90) and $\mathrm{Zn}_{1}$ (58.07). The minimum number of days taken to $50 \%$ flowering (57.22) was recorded in control plot.

The various doses of sulphur significantly influenced number of days taken for $50 \%$ flowering of Indian mustard. Every increasing dose of sulphur significantly increased number of days taken to $50 \%$ flowering. Table 1 reveals that the treatment $S_{0}, S_{1}, S_{2}, S_{3}, S_{4}$ and $\mathrm{S}_{5}$ exhibited significant difference to each other. Significantly highest days taken to $50 \%$ flowering (61.18) was recorded with the treatment of $S_{5}$ followed by $S_{4}(59.99), S_{3}$
(59.05), $S_{2}$ (58.50) and $S_{1}$ (57.74). The lesser number of days taken to $50 \%$ flowering (57.48) of Indian mustard was recorded in control plot.

\section{Number of siliquae plant ${ }^{-1}$}

It is apparent from the Table 1 that the application of different doses of zinc significantly improved the number of siliquae plant $^{-1}$ of Indian mustard during experimentation. The treatment $Z_{1}$ and $Z_{2}$, $\mathrm{Zn}_{2}$ and $\mathrm{Zn}_{3}, \mathrm{Zn}_{3}$ and $\mathrm{Zn}_{4}$ and $\mathrm{Zn}_{4}$ and $\mathrm{Zn}_{5}$ did not show significant differences to each other (Table 1). Significantly maximum number of siliquae plant ${ }^{-1}$ (279.76) of Indian mustard was obtained with the treatment of $\mathrm{Zn}_{5}$ as compared to rest of the treatments. The minimum number of siliquae plant ${ }^{-1}$ (250.62) of Indian mustard was obtained in without zinc applied plot.

The application of sulphur expressed significant effect on number of siliquae plant ${ }^{-1}$ of Indian mustard in Table 1 reveals that the application of various doses of sulphur significantly improved the number of siliquae plant $^{-1}$ of Indian mustard. The treatment $S_{0}, S_{3}$, $\mathrm{S}_{4}$ and $\mathrm{S}_{5}$ expressed significant difference to one another except $S_{1}$ and $S_{2}$. The treatment $S_{1}$ and $S_{2}$ did not show significant differences to each other (Table 1). Application of highest tested dose $\mathrm{S}_{5}$ produced significantly maximum number of siliquae plant ${ }^{-1}$ (301.13) while the minimum number of siliquae plant ${ }^{-1}$ (235.50) of Indian mustard was obtained in control plot.

\section{Length of siliqua}

It is evident from the Table 2 that every increasing dose of zinc significantly increased length of siliqua during experimentation. The treatment $\mathrm{Zn}_{0}, \mathrm{Zn}_{1}, \mathrm{Zn}_{2}, \mathrm{Zn}_{3}$ and $\mathrm{Zn}_{4}$ and $\mathrm{Zn}_{5}$ differed significantly to each other. Significantly maximum length of siliqua (4.89 
$\mathrm{cm})$ of Indian mustard was produced with the application of $12.5 \mathrm{Kg} \mathrm{Zn} \mathrm{ha}{ }^{-1}\left(\mathrm{Zn}_{5}\right)$ and minimum length of siliqua $(4.21 \mathrm{~cm})$ of Indian mustard was obtained in control.

The application of sulphur was significantly influenced the length of siliqua of Indian mustard. Table 2 discloses that the every increasing doses of sulphur significantly increased length of siliqua of Indian mustard. The treatment $S_{0}, S_{1}, S_{2}, S_{3}$ and $S_{4}$ and $S_{5}$ differed significantly to one other. The treatment $\mathrm{S}_{5}$ produced significantly highest length of siliqua $(5.01 \mathrm{~cm})$ as compared to rest of the treatments of sulphur during experimentation. Without sulphur applied plot (control) produced minimum length of siliqua $(4.28 \mathrm{~cm})$ of Indian mustard (Table 2).

\section{Number of seeds siliqua ${ }^{-1}$}

Table 2 reveals that the application of different doses of zinc significantly improved the number of seeds siliqua $^{-1}$ of Indian mustard during investigation. The treatment $\mathrm{Zn}_{0}, \mathrm{Zn}_{1}$ and $\mathrm{Zn}_{2}$ and $\mathrm{Zn}_{3}$ showed significant difference to each other except $Z_{4}$ and $Z_{5}$. The treatment $Z_{4}$ and $Z_{5}$ did not show significant differences to each other (Table 2).

Significantly maximum number of seeds siliqua $^{-1}$ (13.35) was obtained with the treatment of $\mathrm{Zn}_{5}$ which found at par with $\mathrm{Zn}_{4}$ (13.22). The minimum number of seeds siliqua $^{-1}$ (12.25) of Indian mustard was obtained in control plot.

The application of sulphur expressed significant effect on number of seeds siliqua $^{-1}$ (Appendix XI). It is obvious from the Table 2 that the application of various doses of sulphur significantly improved the number of seeds siliqua $^{-1}$ of Indian mustard. The treatment $S_{0}$, $\mathrm{S}_{1}, \mathrm{~S}_{2}, \mathrm{~S}_{3}, \mathrm{~S}_{4}$ and $\mathrm{S}_{5}$ exhibited significant differences to each other. The maximum number of seeds siliqua ${ }^{-1}$ (14.36) was recorded by $\mathrm{S}_{5}$ while minimum (11.82) was found in control plot.

\section{Days to maturity}

The different levels of zinc influenced significantly the days taken to maturity of Indian mustard. Table 2 and disclose that the every increasing levels of zinc significantly increased the number of days taken to maturity of Indian mustard. The differences on days taken to maturity between $\mathrm{Zn}_{5}$ and $\mathrm{Zn}_{4}$ and $Z_{3}$ and $Z_{2}$ were found to be nonsignificant. Significantly highest number of days taken to maturity (134.83) of Indian mustard was recorded with the treatment of $\mathrm{Zn}_{5}$ while minimum number of days taken for maturity (132.69) in absolute control plot.

The application of sulphur exhibited significant effect on days taken to maturity. Table 2 indicates that the application of various doses of sulphur significantly influenced the time taken to maturity of Indian mustard. Treatment $\mathrm{S}_{0}$ recorded significantly least days to maturity (132.11 days) of Indian mustard as compared to other treatment while maximum was found in $S_{5}$ treatment. The treatment $S_{4}$ and $S_{5}$ showed non-significant effect for days taken to maturity to each other than remaining treatments. Maximum days taken for maturity (135.33) of Indian mustard with the application of $\mathrm{S}_{5}$.

\section{Raw seed yield $\left(\mathrm{Kg} \mathrm{plot}^{-1}\right)$}

It is clear that the application of different levels of zinc significantly influenced the raw seed yield of Indian mustard. Raw seed yield $\left(\mathrm{Kg}\right.$ plot $\left.^{-1}\right)$ was significantly increased with every increasing dose of zinc. The treatment $\mathrm{Zn}_{0}$ and $\mathrm{Zn}_{1}, \mathrm{Zn}_{1}$ and $\mathrm{Zn}_{2}, \mathrm{Zn}_{2}$ and $\mathrm{Zn}_{3}$ and $\mathrm{Zn}_{4}$ and $\mathrm{Zn}_{5}$ did not show significant difference for raw seed yield $\left(\mathrm{Kg}\right.$ plot $\left.^{-1}\right)$ of Indian mustard. Treatment $\mathrm{Zn}_{5}$ produced significantly highest raw seed yield (2.44 Kg plot $\left.{ }^{-1}\right)$ and found to be 
at par to $\mathrm{Zn}_{4}\left(2.42 \mathrm{Kg} \mathrm{plot}^{-1}\right)$ while minimum raw seed yield $\left(2.30 \mathrm{Kg} \mathrm{plot}{ }^{-1}\right)$ of Indian mustard was recorded in control plot.

The application of sulphur had influenced significantly on raw seed yield $\left(\mathrm{Kg} \mathrm{plot}^{-1}\right)$ of Indian mustard. Table 2 reveals that every increasing dose of sulphur significantly increased the raw seed yield $\left(\mathrm{Kg}_{\mathrm{glot}}{ }^{-1}\right)$ of Indian mustard. All treatments exhibited significant difference to one another. Highest raw seed yield $\left(2.53 \mathrm{Kg}\right.$ plot $\left.^{-1}\right)$ of Indian mustard was obtained with the application of $\mathrm{S}_{5}$ followed by $\mathrm{S}_{4}$ treatment $\left(2.49 \mathrm{Kg} \mathrm{plot}^{-1}\right)$. The minimum raw seed yield $\left(2.22 \mathrm{Kg} \mathrm{plot}^{-1}\right)$ of Indian mustard was obtained in control plot.

\section{Graded seed yield (Kg plot $\left.{ }^{-1}\right)$}

It is evident that the applications of different levels of zinc significantly affect the graded seed yield of Indian mustard. Table 2 indicates that maximum graded seed yield $(2.28 \mathrm{Kg}$ plot $^{-1}$ ) of Indian mustard was noticed with the treatment of $\mathrm{Zn}_{5}$ which did not differ significantly with $\mathrm{Zn}_{4} \quad\left(2.24 \mathrm{Kg} \mathrm{plot}^{-1}\right)$. The treatment $Z n_{4}$ and $Z_{3}, Z_{3}$ and $Z_{2}, Z_{2}$ and $\mathrm{Zn}_{1}$ and $\mathrm{Zn}_{1}$ and $\mathrm{Zn}_{0}$ did not show significant differences to each other. The minimum graded seed yield $\left(2.13 \mathrm{Kg}\right.$ plot $\left.^{-1}\right)$ of Indian mustard was obtained in control plot.

It is clear that the application of sulphur significantly influenced the graded seed yield $\left(\mathrm{Kg} \mathrm{plot}{ }^{-1}\right)$ of Indian mustard. Graded raw seed yield $\left(\mathrm{Kg} \mathrm{plot}^{-1}\right)$ of Indian mustard was significantly increased with every increasing dose of sulphur (Table 2). The treatments $S_{5}$ and $S_{4}, S_{4}$ and $S_{3}, S_{3}$ and $S_{2}$, and $S_{1}$ and $S_{0}$ exhibited significant difference to each other except $S_{2}$ and $S_{1}$ with respect to raw seed yield $\left(\mathrm{Kg}\right.$ plot $\left.^{-1}\right)$ of Indian mustard. Significantly highest graded seed yield $\left(2.48 \mathrm{Kg} \mathrm{plot}^{-1}\right)$ of Indian mustard was obtained with the treatment of $\mathrm{S}_{5}$ followed by $\mathrm{S}_{4}(2.38 \mathrm{Kg}$ plot $\left.^{-1}\right)$. Without sulphur applied plot recorded minimum graded seed yield $\left(1.96 \mathrm{Kg} \mathrm{plot}^{-1}\right)$ of Indian mustard.

\section{Raw seed yield (Kg ha $\left.{ }^{-1}\right)$}

Data shows that the application of various doses of zinc significantly influenced raw seed yield of Indian mustard. Table 3 reveals that the treatment of $Z_{5}$ and $Z_{4}, Z_{4}$ and $Z_{3}, Z_{3}$ and $\mathrm{Zn}_{2}, \mathrm{Zn}_{2}$ and $\mathrm{Zn}_{1}$ and $\mathrm{Zn}_{1}$ and $\mathrm{Zn}_{0}$ showed non-significant difference on raw seed yield $\left(\mathrm{Kg} \mathrm{ha}^{-1}\right)$ of Indian mustard to each other. The treatment $Z_{5}$ produced significantly highest raw seed yield (2705.59 Kg ha ${ }^{-1}$ ) of Indian mustard as compared to other doses of zinc. The increase in raw seed yield of Indian mustard with the application of $\mathrm{Zn}_{5}$ to the extent of $0.94,2.13,3.48,4.70$ and $5.83 \%$ than $\mathrm{Zn}_{4}, \mathrm{Zn}_{3}, \mathrm{Zn}_{2}, \mathrm{Zn}_{1}$ and $\mathrm{Zn}_{0}$, respectively. Without zinc applied plot recorded minimum raw seed yield $\left(2556.48 \mathrm{Kg} \mathrm{ha}^{-1}\right)$ of Indian mustard.

It is evident that the application of sulphur significantly influenced the raw seed yield of Indian mustard. Table 3 shows that the treatment $S_{5}$ and $S_{4}, S_{4}$ and $S_{3}, S_{3}$ and $S_{2}, S_{2}$ and $S_{1}$ and $S_{1}$ and $S_{0}$ exhibited significant difference on raw seed yield $\mathrm{Kg} \mathrm{ha}^{-1}$ of Indian mustard. Significantly highest raw seed yield (2816.19 $\mathrm{Kg} \mathrm{ha}^{-1}$ ) of Indian mustard was obtained with the treatment $\mathrm{S}_{5}$ as compared to rest of the doses of sulphur. The increase in raw seed yield of Indian mustard with the application of $S_{5}$ to the tune of 2.06, 6.57, 9.27, 11.27 and $14.29 \%$ than $\mathrm{S}_{4}, \mathrm{~S}_{3}, \mathrm{~S}_{2}, \mathrm{~S}_{1}$ and $\mathrm{S}_{0}$, respectively. The minimum raw seed yield (2464.03 $\mathrm{Kg} \mathrm{ha}^{-1}$ ) was obtained in control.

\section{Graded seed yield (Kg ha $\left.{ }^{-1}\right)$}

The application of different doses of zinc significantly influenced the graded seed yield $\left(\mathrm{Kg} \mathrm{ha}^{-1}\right)$ of Indian mustard. Table 3 discloses that the every increment of dose of zinc significantly increased the graded seed yield 
of Indian mustard. Treatment $\mathrm{Zn}_{5}$ and $\mathrm{Zn}_{4}, \mathrm{Zn}_{4}$ and $Z_{3}$ and $Z_{3}$ and $Z_{2}$ did not show significant difference with respect to graded seed yield of Indian mustard. Treatment $\mathrm{Zn}_{5}$ had produced significantly highest graded seed yield $\left(2502.62 \mathrm{Kg} \mathrm{ha}^{-1}\right)$ of Indian mustard followed by $\mathrm{Zn}_{4}\left(2482.54 \mathrm{Kg}\right.$ ha $\left.{ }^{-1}\right)$ and $\mathrm{Zn}_{3}$ $\left(2448.67 \mathrm{Kg} \mathrm{ha}^{-1}\right)$. The increase in graded seed yield of Indian mustard with the application of $\mathrm{Zn}_{5}$ to the tune of $0.81,2.20$, 3.50, 4.31 and 5.61\% than $Z_{4}, Z_{3}, Z_{2}, Z_{1}$ and $\mathrm{Zn}_{0}$, respectively. The minimum graded seed yield (2369.68 Kg ha ${ }^{-1}$ ) of Indian mustard was obtained in control.

It is clear that the application of various doses of sulphur significantly influenced graded seed yield of Indian mustard. It is apparent from the Table 3 that the enhancement in the graded seed yield of Indian mustard was accompanied by increase in the doses of sulphur applied. The treatment $S_{5}$ and $S_{4}, S_{4}$ and $S_{3}, S_{3}$ and $S_{2}, S_{2}$ and $S_{1}$ and $S_{1}$ and $S_{0}$ exhibited significant difference for graded seed yield $\left(\mathrm{Kg} \mathrm{ha}^{-1}\right)$ of Indian mustard from each other. Significantly highest graded seed yield (2747.15 Kg ha ${ }^{-1}$ ) of Indian mustard was recorded with the application of $S_{5}$ followed by $\mathrm{S}_{4}\left(2639.08 \mathrm{Kg} \mathrm{ha}^{-1}\right)$ and $\mathrm{S}_{3}$ treatment $\left(2453.22 \mathrm{Kg} \mathrm{ha}^{-1}\right)$. The increase in the graded seed yield of Indian mustard with the application of $\mathrm{S}_{5}$ to the tune of $4.09,11.98$, 17.04, 21.45 and $26.32 \%$ than $\mathrm{S}_{4}, \mathrm{~S}_{3}, \mathrm{~S}_{2}, \mathrm{~S}_{1}$ and $S_{0}$, respectively. The minimum graded yield $\left(2174.73 \mathrm{Kg} \mathrm{ha}^{-1}\right)$ of Indian mustard was obtained with control.

\section{0-seed weight}

It is clear that the application of zinc significantly influenced the 1000 -seed weight (g) of Indian mustard. The effect on 1000-seed weight between $Z_{5}$ and $Z_{4}, Z_{4}$ and $Z_{3}$ and $\mathrm{Zn}_{2}$ and $\mathrm{Zn}_{1}$ were non-significant to each other. Significantly highest 1000 -seed weight $(5.34 \mathrm{~g})$ of Indian mustard was obtained with the application of $\mathrm{Zn}_{5}$ followed by $\mathrm{Zn}_{4}(5.31 \mathrm{~g})$,
$\mathrm{Zn}_{3}(5.30 \mathrm{~g}), \mathrm{Zn}_{2}(5.24 \mathrm{~g})$ and $\mathrm{Zn}_{1}(5.20 \mathrm{~g})$ while minimum 1000 -seed weight $(5.07 \mathrm{~g})$ of Indian mustard was obtained with control plot.

The application of different levels of sulphur significantly influenced the 1000 -seed weight (g) of Indian mustard. It was observed that every increasing dose of sulphur significantly increased the 1000-seed weight of Indian mustard. Table 3 reveals that the treatment $S_{5}$ and $S_{4}, S_{4}$ and $S_{3}, S_{3}$ and $S_{2}, S_{2}$ and $S_{1}$ and $S_{1}$ and $S_{0}$ had exhibited significant difference to each other. Significantly highest 1000-seed weight $(5.72 \mathrm{~g})$ of Indian mustard was obtained with the application of $\mathrm{S}_{5}$. While lowest 1000seed weight $(4.86 \mathrm{~g})$ of Indian mustard was obtained in control plot.

An application of zinc and sulphur had affected significantly to yield and yield attributing parameters under study. Various levels of zinc and sulphur applied showed significant effect. The number of primary and secondary branches plant $^{-1}$ was registered highest with the application of $10.0 \mathrm{Kg} \mathrm{Zn} \mathrm{ha}{ }^{-1}$ and $50 \mathrm{Kg} \mathrm{S}^{-}$ 1. Increasing doses of zinc and sulphur had increased the number of primary and secondary branches plant $^{-1}$. These results are in close conformity with the findings of Verma et al., (2012), Dubey et al., (2013). The interaction of sulphur and zinc influenced significantly to the number of primary and secondary branches plant $^{-1}$ of Indian mustard. The combination of $10.0 \mathrm{Kg} \mathrm{Zn} \mathrm{ha}{ }^{-1}+50 \mathrm{Kg} \mathrm{S} \mathrm{ha}{ }^{-1}$ recorded maximum number of primary and secondary branches plant ${ }^{-1}$. These results are in close conformity with the findings of Subash and Tripathi (2011), Singh et al., (2012).

The application of zinc and sulphur individually as well as combined exhibited significant effect with respect to plant height. Significantly highest plant height was obtained with the application of $12.5 \mathrm{Kg} \mathrm{Zn} \mathrm{ha}^{-1}$ and 50 $\mathrm{Kg} \mathrm{S} \mathrm{ha}{ }^{-1}$ than rest of the doses of sulphur. 
Table.1 Effect of Zinc and Sulphur on Plant Height (cm), Primary Branches, Secondary Branches, Days to 50\% Flowering, Number of Siliquae in Indian Mustard Variety Urvashi

\begin{tabular}{|c|c|c|c|c|c|c|c|c|c|c|c|c|c|c|c|}
\hline \multirow{2}{*}{$\begin{array}{l}\text { Treatment } \\
\begin{array}{l}\text { Zinc levels } \\
\left(\mathrm{kg} \mathrm{ha}^{-1}\right)\end{array}\end{array}$} & \multicolumn{3}{|c|}{ Plant Height (cm) } & \multicolumn{3}{|c|}{ Primary Branches } & \multicolumn{3}{|c|}{ Secondary Branches } & \multicolumn{3}{|c|}{ Days to $50 \%$ Flowering } & \multicolumn{3}{|c|}{ Number of Siliquae } \\
\hline & $\begin{array}{l}\text { 2011- } \\
2012\end{array}$ & $\begin{array}{l}2012- \\
2013\end{array}$ & Pooled & $\begin{array}{l}\text { 2011- } \\
2012\end{array}$ & $\begin{array}{l}2012- \\
2013\end{array}$ & Pooled & $\begin{array}{l}\text { 2011- } \\
2012\end{array}$ & $\begin{array}{l}2012- \\
2013\end{array}$ & Pooled & $\begin{array}{l}\text { 2011- } \\
2012\end{array}$ & $\begin{array}{l}2012- \\
2013\end{array}$ & Pooled & $\begin{array}{l}2011- \\
2012\end{array}$ & $\begin{array}{l}\text { 2012- } \\
2013\end{array}$ & Pooled \\
\hline $0.0\left(\mathbf{Z n}_{0}\right)$ & 177.20 & 175.46 & 176.33 & 5.61 & 5.68 & 5.64 & 9.49 & 9.90 & 9.69 & 56.87 & 57.57 & 57.22 & 242.62 & 258.63 & 250.62 \\
\hline $2.5\left(\mathrm{Zn}_{1}\right)$ & 179.33 & 176.72 & 178.01 & 5.88 & 5.94 & 5.91 & 9.67 & 10.13 & 9.90 & 57.73 & 58.42 & 58.07 & 262.10 & 265.27 & 263.69 \\
\hline $5.0\left(\mathbf{Z n}_{2}\right)$ & 180.21 & 178.29 & 179.26 & 6.11 & 6.17 & 6.14 & 9.97 & 10.39 & 10.18 & 58.68 & 59.12 & 58.90 & 268.57 & 268.50 & 268.53 \\
\hline $7.5\left(\mathbf{Z n}_{3}\right)$ & 180.78 & 179.20 & 180.00 & 6.30 & 6.34 & 6.32 & 10.49 & 10.84 & 10.67 & 59.50 & 59.47 & 59.48 & 273.95 & 271.31 & 272.63 \\
\hline $10.0\left(\mathrm{Zn}_{4}\right)$ & 181.32 & 179.85 & 180.58 & 6.76 & 6.72 & 6.74 & 11.09 & 11.38 & 11.23 & 60.06 & 60.02 & 60.04 & 277.94 & 277.35 & 277.65 \\
\hline $12.5\left(\mathrm{Zn}_{5}\right)$ & 182.01 & 180.67 & 181.34 & 6.86 & 6.77 & 6.81 & 11.19 & 11.57 & 11.38 & 60.25 & 60.23 & 60.24 & 280.66 & 278.85 & 279.76 \\
\hline $\mathrm{SE}(\mathrm{d})$ & 0.58 & 0.44 & 0.35 & 0.16 & 0.12 & 0.10 & 0.10 & 0.12 & 0.07 & 0.23 & 0.21 & 0.15 & 11.44 & 2.85 & 5.90 \\
\hline $\begin{array}{l}\text { CD } \\
(p=0.05)\end{array}$ & 1.15 & 0.88 & 0.69 & 0.31 & 0.25 & 0.20 & 0.20 & 0.22 & 0.15 & 0.46 & 0.41 & 0.30 & 22.90 & 5.70 & 11.62 \\
\hline \multicolumn{16}{|c|}{ Sulphur levels $\left(\mathrm{kg} \mathrm{ha}^{-1}\right)$} \\
\hline $0\left(\mathbf{S}_{\mathbf{0}}\right)$ & 175.74 & 173.59 & 174.67 & 4.41 & 4.51 & 4.46 & 8.66 & 8.77 & 8.72 & 57.63 & 57.33 & 57.48 & 230.06 & 240.93 & 235.50 \\
\hline $10\left(S_{1}\right)$ & 177.18 & 175.56 & 176.37 & 5.36 & 5.43 & 5.39 & 9.08 & 9.17 & 9.13 & 57.87 & 57.62 & 57.74 & 252.47 & 252.37 & 252.42 \\
\hline $20\left(S_{2}\right)$ & 179.46 & 176.83 & 178.14 & 5.93 & 6.01 & 5.97 & 9.63 & 10.00 & 9.82 & 58.31 & 58.70 & 58.50 & 262.57 & 262.21 & 262.39 \\
\hline $30\left(\mathbf{S}_{3}\right)$ & 181.12 & 178.73 & 179.92 & 6.33 & 6.44 & 6.38 & 10.29 & 11.07 & 10.68 & 58.51 & 59.60 & 59.05 & 274.23 & 274.63 & 274.43 \\
\hline $40\left(S_{4}\right)$ & 183.07 & 182.40 & 182.73 & 7.47 & 7.27 & 7.37 & 11.83 & 12.40 & 12.12 & 59.68 & 60.30 & 59.99 & 287.09 & 286.92 & 287.01 \\
\hline $50\left(S_{5}\right)$ & 184.28 & 183.07 & 183.68 & 8.01 & 7.97 & 7.99 & 12.41 & 12.79 & 12.60 & 61.09 & 61.27 & 61.18 & 299.42 & 302.85 & 301.13 \\
\hline SE (d) & 0.51 & 0.71 & 0.53 & 0.15 & 0.12 & 0.10 & 0.07 & 0.14 & 0.08 & 0.08 & 0.07 & 0.53 & 9.93 & 2.91 & 5.17 \\
\hline $\begin{array}{l}\text { CD } \\
(p=0.05)\end{array}$ & 1.14 & 1.58 & 1.09 & 0.34 & 0.31 & 0.22 & 0.16 & 0.30 & 0.16 & 0.17 & 0.15 & 0.11 & 22.11 & 6.47 & 11.51 \\
\hline
\end{tabular}


Table.2 Effect of Zinc and Sulphur on Length of Siliqua $(\mathrm{cm})$, Number of Seeds Siliqua ${ }^{-1}$, Days aken to Maturity, Raw Seed Yield (Kg $\left.\mathrm{Plot}^{-1}\right)$, Graded Seed yield $\left(\mathrm{Kg} \mathrm{Plot}^{-1}\right)$ in Indian Mustard Variety Urvashi

\begin{tabular}{|c|c|c|c|c|c|c|c|c|c|c|c|c|c|c|c|}
\hline \multirow{3}{*}{$\begin{array}{l}\text { Treatment } \\
\text { Zinc levels } \\
\left(\mathrm{kg} \mathrm{ha}^{-1}\right)\end{array}$} & \multirow{2}{*}{\multicolumn{3}{|c|}{ Length of Siliqua (cm) }} & \multirow{2}{*}{\multicolumn{3}{|c|}{ Number of Seeds Siliqua ${ }^{-1}$}} & \multirow{2}{*}{\multicolumn{3}{|c|}{ Days aken to Maturity }} & \multirow{2}{*}{\multicolumn{3}{|c|}{ Raw Seed Yield (Kg Plot $\left.{ }^{-1}\right)$}} & \multirow{2}{*}{\multicolumn{3}{|c|}{$\begin{array}{l}\text { Graded Seed yield (Kg } \\
\text { Plot }^{-1} \text { ) }\end{array}$}} \\
\hline & & & & & & & & & & & & & & & \\
\hline & $\begin{array}{l}2011- \\
2012\end{array}$ & $\begin{array}{l}2012- \\
2013\end{array}$ & Pooled & $\begin{array}{l}\text { 2011- } \\
2012\end{array}$ & $\begin{array}{l}2012- \\
2013\end{array}$ & Pooled & $\begin{array}{l}\text { 2011- } \\
2012\end{array}$ & $\begin{array}{l}2012- \\
2013\end{array}$ & Pooled & $\begin{array}{l}2011- \\
2012\end{array}$ & $\begin{array}{l}2012- \\
2013\end{array}$ & Pooled & $\begin{array}{l}2011- \\
2012\end{array}$ & $\begin{array}{l}2012- \\
2013\end{array}$ & Pooled \\
\hline $0.0\left(\mathbf{Z n}_{0}\right)$ & 4.23 & 4.19 & 4.21 & 12.36 & 12.14 & 12.25 & 132.89 & 133.00 & 132.69 & 2.32 & 2.29 & 2.30 & 2.14 & 2.13 & 2.13 \\
\hline $2.5\left(\mathrm{Zn}_{1}\right)$ & 4.55 & 4.48 & 4.52 & 12.73 & 12.46 & 12.60 & 132.28 & 133.44 & 133.36 & 2.35 & 2.30 & 2.33 & 2.17 & 2.14 & 2.16 \\
\hline $5.0\left(\mathbf{Z n}_{2}\right)$ & 4.64 & 4.59 & 4.61 & 12.93 & 12.72 & 12.82 & 133.94 & 133.78 & 133.86 & 2.39 & 2.32 & 2.35 & 2.21 & 2.16 & 2.19 \\
\hline $7.5\left(\mathbf{Z n}_{3}\right)$ & 4.75 & 4.70 & 4.73 & 13.12 & 12.89 & 13.00 & 134.39 & 134.28 & 134.34 & 2.43 & 2.33 & 2.38 & 2.24 & 2.17 & 2.21 \\
\hline $10.0\left(\mathbf{Z n}_{4}\right)$ & 4.83 & 4.76 & 4.79 & 13.25 & 13.19 & 13.22 & 134.78 & 134.50 & 134.64 & 2.47 & 2.36 & 2.42 & 2.28 & 2.20 & 2.24 \\
\hline $12.5\left(\mathrm{Zn}_{5}\right)$ & 4.94 & 4.83 & 4.89 & 13.47 & 13.22 & 13.35 & 134.17 & 134.50 & 134.83 & 2.53 & 2.35 & 2.44 & 2.30 & 2.25 & 2.28 \\
\hline $\operatorname{SE}(d)$ & 0.07 & 0.02 & 0.02 & 0.14 & 0.52 & 0.07 & 0.32 & 0.34 & 0.23 & 0.01 & 0.02 & 0.01 & 0.05 & 0.04 & 0.03 \\
\hline $\begin{array}{l}\text { CD } \\
(p=0.05)\end{array}$ & 0.08 & 0.05 & 0.05 & 0.29 & 0.10 & 0.15 & 0.64 & 0.68 & 0.46 & 0.02 & 0.05 & 0.03 & 0.09 & 0.08 & 0.06 \\
\hline \multicolumn{16}{|c|}{ Sulphur levels $\left(\mathrm{kg} \mathrm{ha}^{-1}\right)$} \\
\hline $\mathbf{0}\left(\mathbf{S}_{\mathbf{0}}\right)$ & 4.32 & 4.25 & 4.28 & 11.87 & 11.76 & 11.82 & 132.50 & 131.72 & 132.11 & 2.24 & 2.29 & 2.22 & 1.97 & 1.95 & 1.96 \\
\hline $10\left(S_{1}\right)$ & 4.42 & 4.45 & 4.43 & 12.14 & 12.08 & 12.11 & 133.22 & 133.22 & 133.22 & 2.31 & 2.30 & 2.28 & 2.06 & 2.06 & 2.06 \\
\hline $20\left(S_{2}\right)$ & 4.52 & 4.49 & 4.51 & 12.43 & 12.35 & 12.39 & 133.67 & 133.56 & 133.61 & 2.36 & 2.32 & 2.32 & 2.14 & 2.09 & 2.11 \\
\hline $30\left(S_{3}\right)$ & 4.67 & 4.65 & 4.66 & 12.86 & 12.93 & 12.89 & 134.33 & 134.39 & 134.36 & 2.43 & 2.33 & 2.38 & 2.25 & 2.18 & 2.21 \\
\hline $40\left(S_{4}\right)$ & 4.90 & 4.81 & 4.85 & 13.67 & 13.68 & 13.67 & 134.89 & 135.28 & 135.08 & 2.54 & 2.36 & 2.49 & 2.41 & 2.34 & 2.38 \\
\hline $50\left(S_{5}\right)$ & 5.12 & 4.90 & 5.01 & 14.90 & 13.82 & 14.36 & 135.33 & 135.33 & 135.33 & 2.60 & 2.35 & 2.53 & 2.52 & 2.43 & 2.48 \\
\hline SE (d) & 0.04 & 0.02 & 0.03 & 0.21 & 0.05 & 0.11 & 0.42 & 0.27 & 0.24 & 0.01 & 0.02 & 0.01 & 0.04 & 0.03 & 0.02 \\
\hline $\begin{array}{l}\text { CD } \\
(p=0.05)\end{array}$ & 0.09 & 0.05 & 0.06 & 0.47 & 0.11 & 0.22 & 0.94 & 0.59 & 0.51 & 0.02 & 0.04 & 0.02 & 0.08 & 0.06 & 0.05 \\
\hline
\end{tabular}


Table.3 Effect of Zinc and Sulphur on Raw Seed Yield $\left(\mathrm{Kg} \mathrm{ha}^{-1}\right)$, Graded Seed Yield (Kg ha $\left.{ }^{-1}\right), 1000-$ Seed Weight (g) in Indian Mustard Variety Urvashi

\begin{tabular}{|c|c|c|c|c|c|c|c|c|c|}
\hline \multirow{2}{*}{$\begin{array}{l}\text { Treatment } \\
\text { Zinc levels } \\
\left(\mathrm{kg} \mathrm{ha}^{-1}\right)\end{array}$} & \multicolumn{3}{|c|}{ Raw Seed Yield $\left(\mathrm{Kg} \mathrm{ha}^{-1}\right)$} & \multicolumn{3}{|c|}{ Graded Seed Yield $\left(\mathrm{Kg} \mathrm{ha}^{-1}\right)$} & \multicolumn{3}{|c|}{ 1000-Seed Weight (g) } \\
\hline & $\begin{array}{l}\text { 2011- } \\
2012\end{array}$ & $\begin{array}{l}2012- \\
2013\end{array}$ & Pooled & $\begin{array}{l}\text { 2011- } \\
2012\end{array}$ & $\begin{array}{l}2012- \\
2013\end{array}$ & Pooled & $\begin{array}{l}\text { 2011- } \\
2012\end{array}$ & $\begin{array}{l}2012- \\
2013\end{array}$ & Pooled \\
\hline $0.0\left(\mathbf{Z n}_{0}\right)$ & 2571.55 & 2541.42 & 2556.48 & 2378.51 & 2360.84 & 2369.68 & 5.21 & 4.94 & 5.07 \\
\hline $2.5\left(\mathrm{Zn}_{1}\right)$ & 2609.18 & 2559.10 & 2584.14 & 2415.34 & 2383.14 & 2399.24 & 5.33 & 5.07 & 5.20 \\
\hline $5.0\left(\mathbf{Z n}_{2}\right)$ & 2651.59 & 2577.60 & 2614.60 & 2452.86 & 2383.24 & 2418.05 & 5.36 & 5.13 & 5.24 \\
\hline $7.5\left(\mathrm{Zn}_{3}\right)$ & 2698.21 & 2600.07 & 2649.14 & 2493.84 & 2403.49 & 2448.67 & 5.43 & 5.17 & 5.30 \\
\hline $10.0\left(\mathbf{Z n}_{4}\right)$ & 2731.61 & 2629.05 & 2680.33 & 2527.02 & 2443.06 & 2482.54 & 5.46 & 5.20 & 5.31 \\
\hline $12.5\left(\mathrm{Zn}_{5}\right)$ & 2775.44 & 2635.73 & 2705.59 & 2560.58 & 2444.66 & 2502.62 & 5.44 & 5.24 & 5.34 \\
\hline $\operatorname{SE}(d)$ & 37.99 & 32.43 & 25.31 & 36.82 & 31.79 & 24.13 & 0.04 & 0.02 & 0.02 \\
\hline $\begin{array}{l}\text { CD } \\
(p=0.05)\end{array}$ & 75.99 & 64.87 & 50.12 & 73.66 & 63.58 & 47.78 & 0.08 & 0.05 & 0.05 \\
\hline \multicolumn{10}{|c|}{ Sulphur levels $\left(\mathrm{kg} \mathrm{ha}^{-1}\right)$} \\
\hline $\mathbf{0}\left(\mathbf{S}_{\mathbf{0}}\right)$ & 2484.51 & 2443.54 & 2464.03 & 2186.94 & 2162.52 & 2174.73 & 4.95 & 4.77 & 4.86 \\
\hline $10\left(S_{1}\right)$ & 2559.63 & 2502.39 & 2531.01 & 2290.87 & 2232.97 & 2261.92 & 5.11 & 4.89 & 4.99 \\
\hline $20\left(S_{2}\right)$ & 2617.76 & 2536.71 & 2577.24 & 2373.13 & 2321.23 & 2347.18 & 5.22 & 4.92 & 5.07 \\
\hline $30\left(S_{3}\right)$ & 2688.75 & 2596.13 & 2642.44 & 2489.47 & 2416.98 & 2453.22 & 5.40 & 5.15 & 5.27 \\
\hline $40\left(S_{4}\right)$ & 2819.60 & 2704.14 & 2759.37 & 2682.19 & 2595.97 & 2639.08 & 5.68 & 5.45 & 5.56 \\
\hline $50\left(S_{5}\right)$ & 2877.32 & 2755.06 & 2816.19 & 2800.55 & 2693.74 & 2747.15 & 5.86 & 5.57 & 5.72 \\
\hline SE (d) & 32.71 & 31.66 & 21.82 & 11.02 & 13.21 & 15.90 & 0.04 & 0.03 & 0.03 \\
\hline $\begin{array}{l}\text { CD } \\
(p=0.05)\end{array}$ & 72.89 & 70.54 & 45.25 & 24.55 & 37.15 & 42.24 & 0.09 & 0.07 & 0.05 \\
\hline
\end{tabular}


An increasing trends in plant height was reported with increasing doses of $\mathrm{Zn}$ and $\mathrm{S}$ application. Similar results were reported by Tripathi et al., (2011), Verma et al., (2012), Dubey et al., (2013). Adequate sulphur supply is required for carbohydrate formation as it plays vital role in photosynthesis by influencing the formation of chlorophyll (Tisdale et al., 1984) which ultimately improved growth and development of crop. The plant height increased significantly with increasing sulphur level up to $50 \mathrm{Kg} \mathrm{S}$ ha $^{-1}$, due to its essentiality in plant cell division especially in the activity of meristematic tissues and shoot development. Importance of sulphur in cell division, cell elongation and cell structure was also stated by (Tisdale et al., 1984). Combination of $7.5 \mathrm{Kg} \mathrm{Zn}+50 \mathrm{Kg}$ $\mathrm{S} \mathrm{ha}^{-1}$ had registered significantly highest plant height during the investigation.

As far as days to taken 50 per cent flowering is concerned, application of various levels of zinc and sulphur exhibited significant effect. The application of zinc and sulphur delayed the 50 per cent flowering. Application of 10.0 $\mathrm{Kg} \mathrm{Zn} \mathrm{ha}{ }^{-1}$ and $50 \mathrm{Kg} \mathrm{S} \mathrm{ha}^{-1}$ delayed the 50 per cent flowering significantly than the lower doses of zinc and sulphur. The interaction effect of different doses of zinc and sulphur did not influence to days taken of 50 per cent flowering of Indian mustard. The combination of $10.0 \mathrm{Kg} \mathrm{Zn} \mathrm{ha}{ }^{-1}$ and $50 \mathrm{Kg} \mathrm{S}^{-1}$ had taken maximum days to 50 per cent flowering while minimum days taken for 50 per cent flowering in absolute control. Maurya (2012) reported that application of $60 \mathrm{Kg} \mathrm{S} \mathrm{ha}^{-1} \mathrm{had}$ taken significantly more time for 50 per cent heading as compared to control in wheat.

Significantly highest days taken to maturity was recorded with the application of tested doses of zinc (10.0 Kg ha $\left.{ }^{-1}\right)$ and sulphur (40 $\mathrm{Kg} \mathrm{ha}^{-1}$ ) as compared to rest of the doses of zinc and sulphur. The minimum number of days taken for maturity in control plot. The interaction effect of zinc and sulphur did not influence significantly on days taken to maturity of Indian mustard.

Application of various doses of zinc and sulphur expressed significant effect on number of siliquae plant ${ }^{-1}$. Application of 50 $\mathrm{Kg} \mathrm{S} \mathrm{ha}{ }^{-1}$ produced significantly more number of siliquae plant ${ }^{-1}$ as compared to rest of the doses of sulphur. Though significantly highest number of siliquae plant ${ }^{-1}$ was produced with the application of $12.5 \mathrm{Kg} \mathrm{Zn}$ $\mathrm{ha}^{-1}$ but it was found to be statistically at par with $7.5 \mathrm{Kg} \mathrm{Zn} \mathrm{ha}{ }^{-1}$. The interaction effect of various levels of zinc and sulphur did not show significant differences on number of siliquae plant $^{-1}$. Significant increase in number of siliquae plant $^{-1}$ due to sulphur application had been reported by Singh et al., (2007), Verma et al., (2012) and Dubey et al., (2013).

The siliqua length was significantly influenced by various doses of zinc and sulphur. Application of highest tested dose of zinc (12.5 Kg ha ${ }^{-1}$ ) and sulphur (50 $\left.\mathrm{Kg} \mathrm{ha}^{-1}\right)$ produced significantly highest length of siliqua as compared to other levels of sulphur and zinc. The increase in length of siliqua of mustard with sulphur application have also been reported by Singh et al., (2007) and Verma et al., (2012). The increase in length of silique of Indian mustard due to zinc application have also been reported by Singh et al., (2007) and Dubey et al., (2013).

The application of various doses of zinc and sulphur showed significant effect on number of seeds siliqua ${ }^{-1}$. The maximum number of seeds siliqua $^{-1}$ was recorded with the application of $10.0 \mathrm{Kg} \mathrm{Zn} \mathrm{ha}^{-1}+50 \mathrm{Kg} \mathrm{S} \mathrm{ha}^{-1}$ while minimum was obtained in without zinc and sulphur applied plot. The increase in number of seeds siliqua ${ }^{-1}$ with the application of sulphur have also been reported by, Singh et al., (2012) and Dubey et al., (2013). 
Increases in number of seeds siliqua ${ }^{-1}$ due to zinc application have also been reported by several workers as such et al., (2007) and Dubey et al., (2013).

As far as concerned with the raw seed yield and graded seed yield exhibited significant effect by application of zinc and sulphur. Significantly highest raw seed yield and graded seed yield ( $\mathrm{Kg} \mathrm{plot}^{-1}$ and $\mathrm{Kg} \mathrm{ha}^{-1}$ ) was produced with the application of $10.0 \mathrm{Kg} \mathrm{Zn}$ $\mathrm{ha}^{-1}$ and $50 \mathrm{Kg} \mathrm{S} \mathrm{ha}{ }^{-1}\left(\mathrm{Zn}_{5} \times \mathrm{S}_{5}\right)$ as compared to rest of the doses of zinc and sulphur. The minimum raw seed yield and graded seed yield was obtained in absolute control plot. The enhancement in the raw seed yield and graded seed yield may be attributed to the increase in morpho-physiological, yield attributes and 1000-seed weight. Progressive increase in seed yield of the crop with sulphur application was due to pivotal role of sulphur in the synthesis of protein and vitamin (Patel et al., 2010). Test weight of seed increased with increasing sulphur levels and was attributed to the better availability and translocation of nutrients as well as photosynthate from source to sink. These results indicated that zinc application had substantial contribution to enhance carbohydrate metabolism, protein synthesis and auxin biosynthesis and these key factors together augmented seed yield. These results are in conformity with the findings of Shekhawat et al., (2012), Verma et al., (2012) and Dubey et al., (2013). The increase in raw and graded seed yield due to application of zinc and sulphur have also been reported by Singh et al., (2007), Patel et al., (2010), Kumar and Trivedi (2011), Verma et al., (2012), Singh et al., (2012).

The effect of various levels of zinc and sulphur did not influence significantly on raw seed yield and graded seed yield of Indian mustard. Numerically highest raw seed yield and graded seed yield ( $\mathrm{Kg}_{\text {plot }}{ }^{-1}$ and $\mathrm{Kg} \mathrm{ha}^{-1}$ ) was recorded with the combination of 12.5 $\mathrm{Kg} \mathrm{Zn} \mathrm{ha}{ }^{-1}+50 \mathrm{Kg} \mathrm{S}$ ha $^{-1}\left(\mathrm{Zn}_{5} \times \mathrm{S}_{5}\right)$ while it was minimum in absolute control plot. Jat et al., (2008) reported that combined application of $2.5 \mathrm{Kg} \mathrm{Zn} \mathrm{ha}^{-1}+40 \mathrm{Kg} \mathrm{S}^{-1}$ significantly increased seed yield and yield attributes of mustard. Similar results were obtained by Verma et al., (2012), Dubey et al., (2013) and Chaudhary et al., (2014).

\section{References}

Anonymous (2004). Sulphur in oil Seed Production, Fertilizer Development and Consultation Organization (FDCO) 204-204. A Bharat Corner Pomposh Enclave, Ne Delhi-110048.

Anonymous (2014). Status Paper on Oil Seeds. Oil Seeds Division, Department of Agriculture and Cooperation, Ministry of Agriculture, Govt. of India, Krishi Bhawan, New Delhi. pp: 133136 and 176-177.

Aulakh, M.S. and Pasricha, N.S. (1988). "Sulphur Fertilization of Oil Seeds for Yield and Quality", in Proceedings of the TSI-FAI Symposium. Sulphur in Agriculture-S-11/3.

Choudhary, P.; Jhajharia, A. and Kumar, R. (2014). Influence of Sulphur and Zinc Fertilization on Yield, Yield Components and Quality Traits of Soybean (Glycine Max L.). The Bioscan., 9 (1): 137-142.

Dubey, S.K.; Tripathi, S.K. and Singh, B. (2013). Effect of Sulphur and Zinc Levels on Growth, Yield and Quality of Mustard (Brassica juncea L. Czern\&Coss). J. Crop Sci. and Tech., 2 (1): $1-11$.

Jat, G.; Sharma, K.K.; Kumawat, B.L. and Bairwa, F.C. (2008). Effect of FYM and Mineral Nutrients on Yield Attributes, Yield and Net Return of Mustard. Annal Plant Soil Res., 10 (1): 92-95.

Katyal, J. C.; Sharma, K. L. and Srinivas, K. 
(1997). Sulphur in Indian Agriculture. pp. KS-2/1-2/12.

Marschner, H. (1995). Mineral Nutrition of Higher Plants. Second Edition, Academic Press New York, pp. 231- 255 and 889.

Patel, J.J.; Gupta, D.G. and Dabhi, M. K. (2010). Response of Sulphur Application on Growth, Yield Attributes and Yield of Mustard Under Gujarat Conditions. Green Farming, 1 (3): 272- 273.

Shekhawat, K.; Rathore, S.S.; Premi, O.P.; Kandpal, B.K. and Chauhan, J.S. (2012). Advances in Agronomic Management of Indian Mustard (Brassica Juncea L. Czern\&Coss). Intern. J. Agron. Article ID 408284, 14.

Singh, B.; Sharma, Y. and Rathore, B.S. (2012). Effect of Sulphur and Zinc on Growth, Yield and Quality of Mustard [Brassica Juncea (L). Czern and Coss.]. Research on Crops, 13 (3): 963-969.

Singh, P.; Kumar, M.; Maurya, C.L. and
Swarnkar, S.K. (2007). Effect of Sulphur and Zinc Nutrients on Growth, Seed Yield and Quality of Indian Mustard [Brassica juncea (L.) Czern and Coss] Varieties. Prog. Agric., 7 (1/2): 124-127.

Subhash, A. and Yadav, K.K. (2007). Effect of Sulphur and Zinc on Growth, Yield, Quality and Net Returns of Mustard [Brassica Juncea (L.) Czern and Coss.]. Current Agric., 31 (1/2): 127-129.

Tisdale, S.L.; Nelson, W.L. and Beaten, J.D. (1984). Zinc in Soil Fertility and Fertilizers, $4^{\text {th }}$ Ed., Macmillan Publishing Company, New York, USA, pp: 382-391.

Tripathi, M.K.; Chaturvedi, S.; Shukla, D.K. and Saini, S.K. (2011). Influence of Integrated Nutrient Management on Growth, Yield and Quality of Indian Mustard (Brassica Juncea L.) in Tarai Region of Northern India. J. Crop Weed, 7 (2): 104-107.

\section{How to cite this article:}

Vikas Verma, C.L. Maurya, Sourabh Tomar and Rishi Pal Singh. 2018. Effect of Different Levels of Zinc and Sulphur on Yield and Yield Attributing Characters of Indian Mustard. Int.J.Curr.Microbiol.App.Sci. 7(07): 1573-1585. doi: https://doi.org/10.20546/ijcmas.2018.707.186 